\title{
THE EFFECT OF WEED REMOVAL ON THE GROWTH OF YOUNG APRICOT TREES
}

\author{
R.B. MITCHELL and R.J. ABERNETHY \\ Invermay Agricultural Centre, Private Bag, Mosgiel
}

\section{SUMMARY}

The effect of timing of weed control on the growth of V66 apricots in their first year was measured. Hand weeding treatments began at monthly intervals starting 1 to 7 months after planting. Single and double applications of simazine/terbacil 1 and 4 months after planting, were included for comparison. Results showed a positive relationship between both bud growth and butt circumference and the length of time for which weeds were removed. Tree growth in both simazine/terbacil treatments were equal to that in the best handweeded treatments. The effect of weed competition on trees in the first year persisted to the second year.

\section{INTRODUCTION}

Trials carried out in Hawkes Bay (Hartley 1987) and in Central Otago (Mitchell 1987) have shown that dormant bud plantings of stonefruit can tolerate a wide range of residual herbicides. Tree growth in herbicide treated plots was comparable to growth in plots which were handweeded in the year of planting. However, the beneficial effect of weed removal and the possible detrimental effect of herbicide uptake have not been separated in previous work. It was also not known at what stage weed growth exerts the most influence on the developing tree. Hartley (1988) reported that if weeds or clover were controlled by late October the effect on tree growth was not serious but any further delay in control resulted in a significant reduction in tree size.

The objective of this trial was to determine the effects of weed competition on the growth of young apricot trees.

\section{MATERIALS AND METHODS}

The trial was sited on an irrigated Molyneux shallow loamy sand near Alexandra. The V66 apricot dormant buds grafted on Golden Queen peach stock were planted on 1.8.87 in two ridged rows $2.5 \mathrm{~m}$ apart. The trial consisted of nine treatments (seven hoeing and two herbicide) replicated four times in a randomised block design. Each plot contained three dormant buds planted $2 \mathrm{~m}$ apart. In the herbicide treated plots a $1.5 \mathrm{~m}$ wide band was sprayed on either side of the planted row. Hand hoeing in the first treatment began on 3.9.87 although regular weeding did not start until 20.10.87 after new season's weed growth had commenced. The date of the first weeding for each treatment is shown in Table 1. After the initial hoeing, weeds were removed at monthly intervals until 20.4.88 when weed growth had virtually ceased.

The herbicide treatments consisted of a tank mix of simazine (Rural Flowable Simazine) and terbacil (Sinbar) each at $0.5 \mathrm{~kg} / \mathrm{ha}$. Both treatments were applied on 3.9 .87 , with the double application receiving a repeat spraying on 16.12 .87 . On the first spraying date, dormant buds were not protected from spray contact, but plastic sleeves were used to protect new bud growth in mid December.

Adequate soil moisture levels were maintained over the growing season by overhead sprinklers. The trial area also received five applications of paraquat/diquat (Preeglone) $0.72 \mathrm{~kg} / \mathrm{ha}$ between November 1988 and April 1989.

New bud growth (height above bud union) was measured on 20.1 .88 and both height and butt circumference (taken $10 \mathrm{~cm}$ above bud union) were measured on 27.5.88 and 17.4.89. Up to 16.12 .87 those treatments which had been weeded previously were visually assessed for weed cover, but after this date all treatments were assessed for percent cover of weeds.

Proc. 42nd N.Z. Weed and Pest Control Conf. 


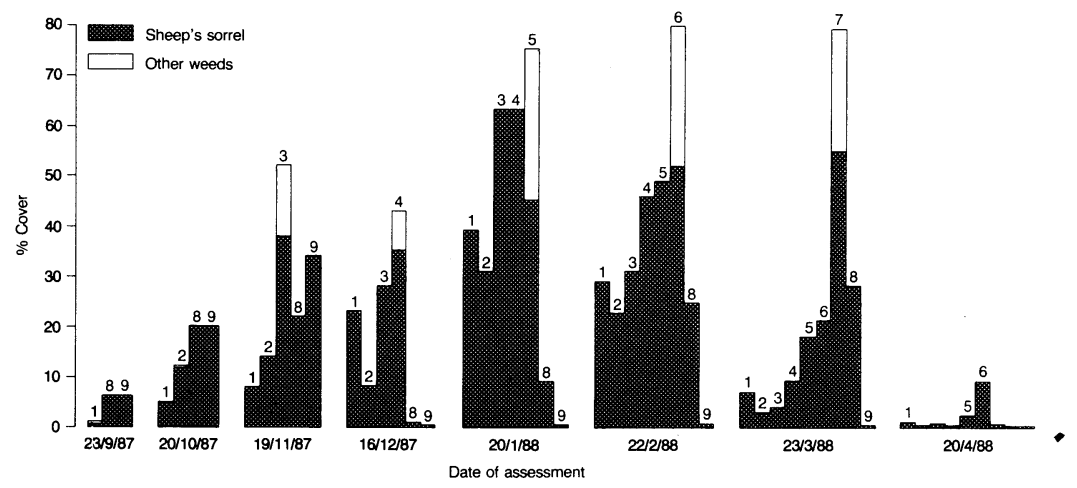

Fig. 1: Percent cover of sheep's sorrel and other weeds at first weeding/spraying date for each treatment and sheep's sorrel in each subsequent month. Treatment numbers (Table 1) are shown over each bar.

\section{RESULTS}

Figure 1 shows the percentage weed cover on the first weeding date for each treatment. Sheep's sorrel (Rumex acetosella) was the dominant weed in the trial, with lesser amounts of woolly mullein (Verbascum thapsus) viper's bugloss (Echium vulgare), fescue (Festuca spp). and downy brome (Bromus tectorum). After hoeing, sheep's sorrel rhizomes recovered rapidly and it proved impossible to keep plots completely free of this weed between the monthly visits.

The time between planting and the start of weeding had a highly significant effect on developing bud growth. Buds broke dormancy in October and as early as mid January bud growth in treatments weeded before mid November was significantly greater than bud growth in later weeded treatments (Table 1). This growth advantage was maintained for the growing season and the effect of weed competition in the later weeded treatments became more obvious as the season progressed. Between January and May 1988 trees in plots weeded before mid December increased in height by an average of $78 \%$. Trees in plots weeded after this date recorded an average height increase of only $20 \%$. In 1988-89, trees in treatments weeded by mid November 1987 and the two herbicide treatments maintained their growth advantage over the trees in later weeded plots (Table 1). It was observed that V66 apricots have a vigorous growing main leader and measurements taken on 17.4 .89 were considered to reflect the strength of the trees. There was a direct relationship betwen butt and height measurements.

Bud growth in the herbicide treatments was similar to the best weeding treatments, with the repeat application giving no significant improvement in tree growth over the single spraying (Table 1). Both treatments, however, required an application of glyphosate (Roundup) at $2.1 \mathrm{~kg} / \mathrm{ha}$ in November 1987 to control surviving sheep's sorrel and the single spray treatment needed a further application of glyphosate in February 1989. After the repeat spraying of simazine/terbacil on 16.12 .87 sheep's sorrel regrowth remained at less than $1 \%$ ground cover for the remainder of the season. Woolly mullein, viper's bugloss, annual weeds and grasses were well controlled by the simazine/terbacil treatments. 
TABLE 1: Growth of V66 apricots on Golden Queen peach stock as af fected by time of hand hoeing and herbicide treatments.

\begin{tabular}{llrrrrr}
\hline \multirow{2}{*}{ Treatment } & $\begin{array}{c}\text { TREE MEASUREMENTS (cm) } \\
\text { Date of first } \\
\text { weeding }\end{array}$ & \multicolumn{3}{c}{$\begin{array}{c}\text { Height above } \\
\text { bud union }\end{array}$} & \multicolumn{3}{c}{$\begin{array}{c}\text { Butt } \\
\text { circumference }\end{array}$} \\
& & 20.1 .88 & 27.5 .88 & 17.4 .89 & 27.5 .88 & 17.4 .89 \\
\hline 1 & 3.9 .87 & 85 & 148 & 265 & 5.6 & 12.2 \\
2 & 20.10 .87 & 79 & 132 & 266 & 5.1 & 12.5 \\
3 & 19.11 .87 & 66 & 127 & 266 & 4.0 & 11.4 \\
4 & 16.12 .87 & 52 & 93 & 223 & 3.4 & 9.8 \\
5 & 20.1 .88 & 45 & 61 & 232 & 2.4 & 9.4 \\
6 & 22.2 .88 & 39 & 42 & 204 & 1.7 & 8.0 \\
7 & 23.3 .88 & 41 & 48 & 205 & 1.9 & 7.6 \\
8 & simazine/terbacil 3.9.87 & 73 & 134 & 281 & 4.6 & 12.0 \\
9 & simazine/terbacil & & & & & \\
& $3.9 .87 \& 16.12 .87$ & 82 & 148 & 262 & 5.3 & 12.2 \\
& LSD 5\% & 17 & 30 & 38 & 1.0 & 1.6 \\
& $1 \%$ & 23 & 41 & 51 & 1.4 & 2.2 \\
\hline
\end{tabular}

Weed cover increased rapidly with the rise in soil and air temperatures in November. The failure to control sheep's sorrel by handweeding and its capacity to continually regenerate is illustrated in Figure 1. Woolly mullein and viper's bugloss occupied up to $14 \%$ and $18 \%$ cover respectively when at the large rosette stage in January and February 1988 but after hoeing only traces of each were recorded. Downy brome and fescue germinated throughout the growing season but never reached more than $3 \%$ ground cover.

In the second year the repeat application of paraquat/diquat ensured that weed cover in the trial area remained at a low level during the growing season. By 17.4.89 sheep's sorrel in the treatment first weeded on 23.3.88 occupied $10 \%$ ground cover with $6 \%$ other weeds including moth mullein (Verbascum virgatum), woolly mullein, clover (Trifolium dubium), viper's bugloss and grass. All other treatments contained less than $2 \%$ cover of sheep's sorrel with traces of other weeds.

\section{DISCUSSION AND CONCLUSIONS}

Results from this trial have shown that removal of weeds soon after dormant buds are planted out has a major influence on tree growth. Tree growth rates decreased with increasing time between planting and the first weeding. The data suggest that weeds should be removed before they become well established and start to compete for available moisture and soil nutrients. Hartley (1988) has reported that first year's growth has a significant effect on both numbers and weight of fruit in the second year.

Growth increases in the two herbicide treatments were similar to the best handhoed treatments. This confirms earlier findings by Hartley (1987) and Mitchell (1987) that low rates of certain residual herbicides are well tolerated by dormant bud stonefruit plantings in the year of establishment. The majority of new stonefruit orchards in Central Otago are planted on shallow ridges which precludes mechanical weed control, and handhoeing is not a viable option. Thus, as an alternative, herbicides if used correctly and judiciously, can control germinating, annual, biennial and perennial weeds without adversely affecting tree development. This trial has shown that simazine/terbacil each at $0.5 \mathrm{~kg} / \mathrm{ha}$ applied post-planting for weed control in apricot orchards can give tree growth increases similar to the best hand weeded treatments.

\section{ACKNOWLEDGEMENT}

We would like to thank John Cherry for his help in the field and Warren Galletly for his co-operation with the running of the trial. 


\section{REFERENCES}

Hartley, M.J., 1987. Herbicide tolerance and weed control in young nectarines. Proc. 40th N.Z. Weed and Pest Control Conf.: 140-143.

Hartley, M.J., 1988. Weed control improves the growth and yield of young fruit trees. Proc. 41st N.Z. Weed and Pest Control Conf.: 258-261.

Mitchell, R.B., 1987. Evaluation of herbicides in establishing stonefruit. Proc. 40th N.Z. Weed and Pest Control Conf.: 144-148. 